\title{
MITÄ ON JOHTAMINEN
}

\author{
"Aikuismainen kulttuuri on oppivan organisaation kulttuuri. \\ Tällaisessa organisaatiossa pyritään reflektoinnin kautta oppimaan \\ pois puolustusmekanismeista, jotka haittaavat yksilön ja \\ organisaation kehittymiseen liittyviä pyrkimyksiä. \\ Aikuismaisessa kulttuurissa pyritään jakamaan todellinen, aito \\ informaatio kaikille. Yleisestikin ottaen tilanteet ja roolit pyritään \\ suunnittele maan sellaisiksi, että ihmiset voivat olla aitoja. \\ Näin pyritään minimoimaan puolustusmekanismien käyttöä."
}

Elämme kahden aikakauden murrosvaiheessa. Aikakausia on kuvattu eri nimillä. Niitä on kutsuttu teolliseksi ja informaatio- tai osaamisen yhteiskunnaksi sekä toiseksi ja kolmanneksi aalloksi. Oltiinpa nimestä mitä mieltä hyvänsä, ei ole epäilystä siitä, että elämme murrosvaiheessa. Sille on tyypillistä entisten ajattelutapojen merkityksen väheneminen ja pyrkimys löytää uusia merkitysjärjestelmiä. Murrosvaiheessa meitä ohjaavien uskomuksien syvällisin taso, kulttuurin symbolinen kenttä ja siihen liittyvä myytistö, menettää selitysvoimaansa. Kuitenkaan uudenlaista tapaa ajatella ja hahmottaa ympäristöä ei vielä ole luotu. Uusi visio on vasta hahmottumassa. Kuitenkin sitä voidaan konkretisoida ja tarkastella, mitä se edellyttää johtamiselta.

\section{Organisaatioihin liittyvät ihanteet ovat muuttumassa}

Perinteinen näkökulma organisaatioista on tukeutunut ns. byrokratian ihannemalliin. Byrokratian ihannemallia kuvaa pitkälle viety työnjako, hierarkia, pysyvyys, ja säännöt. Työntekijät ja toimihenkilöt työskentelevät tarkoin määritellyissä rooleissa, joita ohjaavat korkeahkon komentoketjun melko muuttumattomat rakenteet ja pelisäännöt. Organisaatio toimii hitaan muutoksen yhteiskunnissa ja se pyrkii säilyttämään pysyvyyden. Ihmiset ovat "organisaation ihmisiä" ja pyrkivät käyttämään taitonsa yhtiön hyväksi. Johtoa pidetään organisaation "aivoina" ja työntekijöitä organisaation "käsinä". Luovuus ei ole arvossa. Liian poikkeavat, luovat henkilöt ajautuvat organisaation ulkopuolelle "sopeutumattomina". Yrityskulttuuria leimaa pyrkimys voittaa kilpailu kustannuksista piittaamatta, pyrkimys kasvattaa tuotanto mahdollisimman laajalle, pyrkimys saavuttaa turvattu ja arvostettu asema organisaatiolle ja pyrkimys säilyttää tietynlainen ympäristön pysyvyys.

Byrokratian ihannemallin mukaiseen organisoitumiseen on kiinnitetty kriittistä huomiota yhä lisääntyvästi useimmissa viimeaikaisissa organisaatiotarkasteluissa. Nykyisinä yhä lisääntyvän kilpailun, teknillisten uudistusten ja muuttuvien kulutustottumusten aikana byrokraattinen organisaatio näyttää entistäkin vanhanaikaisemmalta ja on yhä ilmeisempää, että tuo organisaatiotyyppi on aikansa elänyt.

Byrokratian ihannemallin mukaisten uskomusten avulla toimintaansa ohjaavat organisaatiot eivät kykene muuttumaan tilanteiden muuttuessa. Byrokratian korvaavan ajattelutavan käyttöönotto on hankalaa, vaikka tiedämme byrokratiaan liittyviä epäkohtia. Muutos on hankalaa siksi, että meidän omat asenteemme ja uskomuksemme ylläpitävät byrokratiaan liittyviä uskomuksia. Byrokraattinen organisaatiomuoto saa ilmiasunsa uskomuksissamme, joita meillä on siitä millainen työyhteisön 
tulee olla. Niinpä byrokraattinen organisaatiomuoto ei häviä ennen kuin uskomuksemme hyvästä työyhteisöstä saa uuden sisällön.

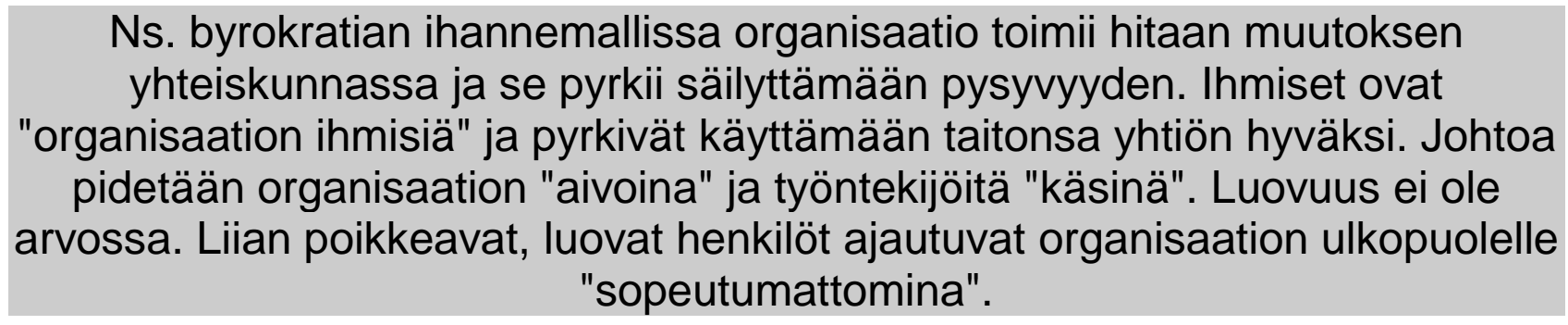

Uudentyyppisen (byrokratian korvaavan) ajattelutavan tarve on tunnistettu jo kauan. Esimerkiksi Warren Bennis totesi jo vuonna 1964 eräässä konferenssiesitelmässään, että organisaatioita tulisi pitää pikemminkin orgaanisina kuin mekanistisina ja yksilöllisen organisoitumisen sijaan tulisi painottaa enemmän ryhmätyötä ja yhteistyötä. Lisäksi Bennis jo tuolloin totesi, että henkilöstö kasvavan koulutustason ja muuttuvien arvostusten vuoksi haluaa sitoutua työhönsä ja osallistua työhönsä liittyvään päätöksentekoon.

Kahdeksankymmentäluvun puolessa välissä uuden ajattelutavan etsiminen oli muuttunut melko selkeäksi pyrkimykseksi korvata vanhat ajattelutavat uudentyyppisellä organisaatioajattelulla. Tuolloin oli myös saatavilla ensimmäisiä näyttöjä siitä, että uudentyyppisille ajatuksille rakentuvat organisaatiot olivat toimivia ja tehokkaampia kuin vanhoille ajatusrakennelmille perustuvat organisaatiot.

Esimerkiksi Richard Walton vertasi vuonna 1985 kahden kemian tehtaan toimintaa ja totesi, että tehokkaampi organisaatio jakautui 10 - 15 henkilön tiimejä, jotka olivat yhteisvastuussa tietyistä toiminnoista. jokaisella tiimin jäsenellä oli koulutus useampaan kuin yhteen tehtävään ja palkkaus riippui siitä, kuinka monia tehtäviä henkilö hallitsee. Tiimeille oli annettu runsaasti koulutusta ja tietoja siitä, millaisilla markkinoilla yritys työskentelee ja millainen kustannusrakenne yrityksellä on. Lisäksi tiimit seurasivat itse toimintansa tuloksia. Tiimien esimiehet toimivat eräänlaisina tiimien valmentajina.

Vähemmän tehokas tehdas oli organisoitunut perinteisen byrokratian ihannemallin mukaisesti tiukkoine tehtäväjärjestelyineen ja kontrolleineen. Tehokkaamman organisaation paremmuus oli Waltonin analyysin mukaan seurausta korkeasta henkilöstön sitoutuneisuudesta sekä johdon ja luottamushenkilöiden hyvästä yhteistyöstä yhteisten päämäärien saavuttamiseksi.

Uudentyyppisen organisoitumisen käytöstä on vähitellen kertynyt tietoja lukuisista organisaatioista. Uudentyyppisiä organisaatioita voitaisiinkin pitää eräänlaisina "aikuismaisen kulttuurin" omaavina organisaatioina.

Aikuismainen kulttuuri on oppivan organisaation kulttuuri. Tällaisissa organisaatioissa pyritään reflektoinnin kautta oppimaan pois puolustautumismekanismeista, jotka haittaavat yksilön ja organisaation kehittymiseen liittyviä pyrkimyksiä.

Aikuismaisessa kulttuurissa pyritään jakamaan todellinen, aito informaatio kaikille. Yleisestikin ottaen tilanteet ja roolit pyritään suunnittelemaan sellaisiksi, että ihmiset voivat olla aitoja. Näin pyritään minimoimaan puolustusmekanismien käyttöä. 
Yhteisesti jaetun tiedon varassa pyritään käymään mahdollisimman avointa keskustelua, jonka seurauksena kaikki vaihtoehdot voidaan käsitellä. Valitun vaihtoehdon hyviä ja huonoja puolia punnitaan yhteisesti. Tämä keskustelu ja yhteispäätös, johon jokainen on osallistunut mahdollistaa valittuun vaihtoehtoon sitoutumisen. Tämä mahdollistaa myös toisen asemaan asettumisen mahdollistumisen kautta perustan ihmisten väliselle yhteistyölle.

Aikuismaiseen kulttuuriin voidaan siirtyä mm. seuraavien muutosten seurauksena:

- sääntöjen ja menettelytapojen tiukan käytön sijalle tulee salliva toimintatapa

- vastuu delegoidaan ryhmille ja yksilöille

- suuntaudutaan tuloksiin

- pyritään avoimeen vuorovaikutukseen

- pyritään korkeaan sitoutuneisuuden tasoon kaikissa tehtävissä

- organisaatiorakenne uudistetaan.

Aikuismaisen kulttuurin omaava organisaatio on matala, kevyt ja vähän organisaatiotasoja omaava verkkomainen rakenne, jossa ihmiset organisoituvat kompetenssin mukaan ja jossa päämäärät välittyvät visioiden kautta. Tällainen organisaatio perustuu ihmisten vastuulliselle työskentelylle.

Aikuismainen kulttuuri on tiimiorganisaatio, joka perustuu itsenäisesti työskentelevien ihmisten toimintaan. jokaisen on ymmärrettävä tiimin tavoitteet ja päämäärät sekä omattava riittävä kompetenssi. Tämä vaatii jatkuvaa henkilöstön kehittämistä. Lisäksi ihmisillä tulee olla kaikki käytettävissä oleva tieto oman toimintansa perustana. Itsenäisen toiminnan syntymisen ehdoton edellytys on, että ihmiset tuntevat, että heihin luotetaan.

Aikuismaisessa kulttuurissa on erityisesti kiinnitetty huomiota työyhteisön innovatiivisuuteen ja henkilöstön sitoutuneisuuteen sekä toimintamahdollisuuksiin.

\section{Uudentyyppisiä organisaatioita voitaisiin pitää eräänlaisina "aikuismaisen kulttuurin" omaavina organisaatioina. Sellaisissa organisaatioissa sääntöjen ja menettelytapojen tiukan käytön sijalle tulee salliva toimintatapa, vastuu delegoidaan ryhmille ja yksilöille, suuntaudutaan tuloksiin, pyritään avoimeen vuorovaikutukseen ja korkeaan sitoutuneisuuden tasoon ja uudistetaan organisaatiorakenne.}

Innovatiivisuuden tutkijat ovat todenneet $\mathrm{mm}$. että innovatiivisuuden ja luovuuden tutkiminen tarjoaa mahdollisuuksia toteuttaa muutoksia organisaatioissa. Muutoksen tarve innovatiivisuuden tutkijoiden mielestä on syntynyt toisaalta organisaation tuottavuuteen ja kilpailukykyyn liittyvissä seikoissa ja toisaalta työelämän laatuun liittyvissä seikoissa. Innovatiivisuuden tutkijat ovat todenneet, että organisaation entistä parempi sopeutuminen ympäristöönsä voidaan toteuttaa mm. innovatiivisten prosessien kautta ja lisäksi ihmiset, jotka ovat voineet käyttää luovuuttaan työyhteisöissä ovat tutkimusten mukaan muita tyytyväisempiä työhönsä.

Innovaatiolla tarkoitetaan sellaisten uusien ajattelumallien tai roolien tietoista käyttöönottoa tai soveltamista, joiden tavoitteena on hyödyttää yksilöä, ryhmää, organisaatiota tai yhteiskuntaa. Innovaatiot voivat vaihdella rutiininomaisista innovaatioista radikaaleihin toimintatapoja täysin muuttaviin innovaatioihin, joiden toteuttamisen edellytyksenä on koko aikaisemman ajattelutavan perusteiden muuttaminen. 
Innovatiivisuutta edesauttaa mm. innovatiivisuudelle suotuisa ilmapiiri ja kulttuuri. johtaminen, joka painottaa yritteliäisyyttä, uudistumista, joustavuutta riskinottoa yhdistyy joidenkin tutkimusten mukaan innovatiivisuuteen.

Aikuismaisen kulttuurin synnyn keskeisenä edellytyksenä on juostavuuden ja innovatiivisuuden ohella yksilön kypsyminen ja pyrkimys aikuismaiseen työskentelyyn. Tämä aikuismainen työskentely puolestaan antaa lisääntyviä mahdollisuuksia organisaatioiden joustavalle sopeutumiselle ympäristöönsä lisääntyvän innovatiivisuuden kautta.

Aikuismaisen työskentelytavan varaan organisoitumisen yhteydessä puhutaan valtuuttamisesta (empowerment), jolla tarkoitetaan sitä, että inhimillistä energiaa vapautetaan inhimillisen energian kontrolloinnin sijasta. Valtuuttamisella tarkoitetaan sallivuutta, suvaitsevuutta ja vapautta. Valtuuttavuuden taustalla on ajatus, että ihmiset voivat saada lisää valtaa ja mahdollisuuksia toisiltaan. Valtuuttamiseen liittyvän ajattelutavan mukaan valta ei ole rajallinen tekijä (nollasummapelin omainen muuttuja, jota voi ainoastaan jakaa), vaan vallan lisääntymisen myötä onnistumisen mahdollisuudet lisääntyvät koko yhteisössä.

Valtuuttaminen liittyy uudenlaiseen tapaan ajatella ja työskennellä. Esimies ei enää ole "sankari", vaan valmentaja, joka kehittää yksilöiden kykyjä ja taitoja sekä tiimien toimivuutta. Tiimissä käytyjen keskusteluiden tuloksena syntyy merkityssisältö, jonka avulla voidaan pyrkiä menestymään, käyttäen ihmisten tietoja, taitoja ja kokemuksia mahdollisimman hyvin hyväksi. Tiimissä itseensä luottavat, sitoutuneet ja kyvykkäät henkilöt osallistuvat vuorovaikutukseen, jonka tuloksena pyritään yhteispäätöksiin ja "voittajavoittaja" suhteisiin, joissa jokainen ryhmän jäsen saavuttaa päämääränsä samalla kun saavutetaan organisaation päämäärät. Tällainen työskentelytapa johtaa sekä yksilön että organisaation hyvinvointiin. Valtuuttamista lisääviä keinoja ovat muun muassa koulutus, tukeminen, avun antaminen ja omasta toiminnasta oppiminen.

\section{Johtamisnäkemysten muutossuuntia}

Empiirinen johtamistaidollinen tutkimus on edennyt eri vaiheiden kautta. Aluksi tutkittiin lähes yksinomaan johtajan ominaisuuksia. Tämä selittyy sillä, että johtajiin liitettiin tuolloin lähes yli-inhimillisiä piirteitä. Näiden piirteiden 1980 avulla heidän kuviteltiin kykenevän mittaviin tekoihin. Myyttejä ylläpidettiin tarinoin suurteoista.

Lukuisat tutkimukset kuitenkin osoittivat, että johtajan ominaisuuksia tutkimalla ei ollut löydettävissä selitystä johtamisen onnistumiseen tai epäonnistumiseen. Niinpä johtamistaidollinen tutkimus eteni johtajan käyttäytymisen tutkimisen kautta tilannepainotteiseen vaiheeseen.

Johtamiseen liittyvän massiivisen tutkimustyön tuloksena on viime aikoina tultu vaiheeseen, jossa johtamista ei yritetä selittää yksinkertaisilla käyttäytymis- tai tilannepainotteisilla malleilla vaan johtamiseen liittyviä tekijöitä laajasti huomioon ottavilla "integroivilla" malleilla. Lisäksi 1980-luvulla alettiin yhä yleisemmin etsiä uusia tarkastelukulmia johtamisen perustaksi. "Integroivien" näkökulmien rinnalle on syntynyt monia ns. ymmärtävän tutkimusperinteen piiriin luettavia malleja johtamisesta. Näille malleille yhteistä on, että niissä pyritään tarkastelemaan prosesseja, joiden kautta merkityssisällöt syntyvät yhteisössä. 
Empiirisessä johtamistaidollisessa tutkimuksessa voidaan erottaa ainakin seuraavat vaiheet:

\begin{tabular}{|c|c|}
\hline ajankohta & suosituin näkökulma \\
\hline $1940-1950$ & $\begin{array}{l}\text { Johtajan ominaisuuksien tarkastelu: } \\
\text { - pyrittiin erottamaan hyvin menestyvä johtaja heikosti menestyvästä heidän ominaisuuksiensa perus- } \\
\text { teella }\end{array}$ \\
\hline $1950-1970$ & $\begin{array}{l}\text { Käyttäytymistieteellinen tarkastelu: } \\
\text { - pyrittiin erottamaan menestyvä johtaja huonosti menestyvästä heidän käyttämänsä johtamistyylin } \\
\text { perusteella }\end{array}$ \\
\hline $1970-1980$ & $\begin{array}{l}\text { Tilannepainotteinen tarkastelu: } \\
\text { - pyrittiin vakioimaan niitä olosuhdetekijöitä, joissa johtaminen tapahtuu ja pyrittiin löytämään } \\
\text { tilanteiden ja johtamistyylien välistä yhteensopivuutta }\end{array}$ \\
\hline 1980 - & $\begin{array}{l}\text { Integroiva tarkastelukulma: } \\
\text { - on alettu yhdistää piirreteoreettisia, käyttäytymispainotteisia ja tilanneteorioita toisiinsa ja asettaa ne } \\
\text { siihen sosiaaliseen ympäristöön, jossa johtaminen tapahtuu Tulkitseva ja ymmärtävä näkökulma: - on } \\
\text { pyritty tulkitsemaan niitä prosesseja, joiden kautta yhteisö luo merkityssisältöjä. }\end{array}$ \\
\hline
\end{tabular}

Johtamista on määritelty lukuisin eri tavoin. Johtaminen liittyy organisaation suunnitteluprosessissa syntyneiden toimintastrategioiden toimeenpanoon ja valvontaan. Perinteisesti johtamiseen on katsottu kuuluvan suunnittelu, organisointi, toimeenpano ja valvonta.

Johtamista voidaan määritellä ainakin ryhmän sosiaalisen prosessin osana, johtajan ominaisuuksien avulla, vaikuttamistapana, valtasuhteena, keinona päämäärään pyrittäessä, sosiaalisena roolina ja sosiaalisen rakenteen osana.

Nykyisin ollaan lähes yhtä mieltä siitä, että johtaminen on sosiaalinen vuorovaikutusprosessi. johtaminen voidaan määritellä vuorovaikutusprosessiksi, jonka avulla pyritään vaikuttamaan ryhmän toimintaan niin, että jokin päämäärä saavutettaisiin. Vuorovaikutusprosessi vaatii vapaaehtoisen yhteistoiminnan aikaansaamista ryhmässä niin, että toiminnot organisoidaan ja toteutetaan koordinoidusti ja päämäärähakuisesti.

\section{Johtamista on määritelty lukuisin eri tavoin. Johtaminen liittyy organisaation suunnitteluprosessissa toimeenpanoon ja valvontaan. \\ Perinteisesti johtamiseen on katsottu kuuluvan suunnittelu, organisointi ja valvonta. Sitä voidaan käsitellä valtasuhteena, vaikuttamistapana sekä sosiaalisen prosessin ja rakenteen osana. Johtaminen voidaan määritellä myös vuorovaikutusprosessiksi, jonka avulla pyritään vaikuttamaan ryhmän toimintaan niin, että jokin päämäärä saavutettaisiin.}

\section{Piirreteoriat}

Johtamisen tieteellinen tutkimus käynnistyi vastauksen hakemisesta kysymykseen, millaisia ominaisuuksia on johtajalla. Perinteisesti ajateltiin, että johtajaksi ei voi oppia, vaan että johtajan ominaisuudet peritään.

Myöhemmin piirreteorioissa luovuttiin tästä oletuksesta ja katsottiin, että johtajan ominaisuudet ovat osin synnynnäisiä ja osin opittuja. Niinpä tutkimuksissa pyrittiin selvittämään, millaisia synnynnäisiä ja opittuja ominaisuuksia johtajilla on. Piirreteorioissa oletettiin, että johtajat poikkeaisivat joidenkin ominaisuuksiensa suhteen alaisistaan. Tutkimuksissa yritettiin selvittää, 
millaisia nämä ominaisuudet olivat. Lisäksi pyrittiin ennustamaan johtajan menestystä hänen ominaisuuksiensa perusteella.

Ralph Stogdillin vuonna 1948 tekemän tutkimuksen mukaan johtajana menestymiseen liittyivät useimmiten älykkyys (23), koulutuksen pituus (22), sosiaalinen osallistuminen (20), itseluottamus (17), pyrkimys vastuullisesti saavuttaa tavoitteita (17), sosiaalinen asema (15) ja sosiaalisuus (14). (Suluissa oleva luku viittaa tutkimuksien lukumäärään, joissa kyseisellä ominaisuudella oli havaittu olevan merkitystä).

Bernard Bassin ja Ralph Stogdillin vuonna 1970 tekemän tutkimuksen mukaan vastaavat tunnusluvut vuosien 1948 ja 1970 välillä tehdyissä tutkimuksissa olivat sosiaalisuus (35), dominanssi (31), itseluottamus (28), älykkyys (25), energisyys (24), halu suoriutua (21), sosiaalinen asema (19), halu ottaa vastuuta (17) ja hallinnolliset taidot (16).

Vaikka yllä olevissa luetteloissa on tietyntyyppisiä yhdenmukaisuuksia voidaan piirreteoreettisen viitekehyksen yleisesti ottaen katsoa epäonnistuneen. Useita vuosikymmeniä kestänyt tutkimustyö ei tuottanut selkeää vastausta siihen, millaisia ominaisuuksia johtajilla on alaisiinsa verrattuna ja millaiset ominaisuudet selittäisivät johtajan menestystä.

Piirreteoreettisen tutkimustyön tuloksena saatiin selville, ettei johtajilla ole sellaisia synnynnäisiä eikä opittuja ominaisuuksia, joiden perusteella he poikkeaisivat muusta väestöstä. johtajat poikkeavat alaisistaan ainoastaan älykkyytensä suhteen, ja on monia muitakin ammatteja, joissa tarvitaan korkeahkoa älykkyyttä.

Piirreteorioiden epäonnistumisen syitä on monia, mutta keskeisimpiä varmasti on, että eri tilanteet vaativat johtajalta erilaisia ominaisuuksia. Piirreteorioissa ei kyetty ottamaan huomioon erilaisten tehtävien, erilaisten alaisten ja erilaisten sosiaalisten tilanteiden vaatimuksia johtajan ominaisuuksilta.

Useilla johtajilla on monia hyviä ominaisuuksia. Nämä ominaisuudet eivät kuitenkaan välttämättä ole samoja kuin muilla johtajilla eivätkä välttämättä erilaisia kuin heidän alaistensa ominaisuudet. Ehkä yleisimmät johtajalta edellytettävät ominaisuudet voidaan kiteyttää älykkyydeksi, sosiaalisuudeksi, suoritussuuntautuneisuudeksi ja ihmisten arvostamiseksi.

\section{Käyttäytymiseen liittyvät teoriat}

Siinä missä piirreteorioissa pyrittiin selittämään johtamista johtajan ominaisuuksien avulla, pyrittiin käyttäytymiseen liittyvissä teorioissa tarkastelemaan pääosin sitä, mitä johtajat tekevät.

Käyttäytymistieteellisessä tarkastelussa painottuivat johtajan roolit, arvot ja asenteet sekä heidän käyttämänsä viestintätavat. Johtajan käyttäytymiseen liittyviä tutkimuksia tehtiin useissa yliopistoissa, ehkä kuuluisimmat Iowan, Ohion ja Michiganin yliopistoissa.

R. Whiten ja R. Lippitin Iowan yliopistossa tekemiä johtamistaidollisia tutkimuksia pidetään tämän tutkimustavan klassikkoina. Kokeet suoritettiin 1930-luvun lopulla. Kokeiden tuloksena todettiin, että kokeeseen osallistuneet pojat arvostivat demokraattista johtamistapaa, koska sen seurauksena syntyi hyvä ryhmähenki ja ystävyyssuhteita ryhmän jäsenten välille. Pojat arvostivat jopa antaa mennä -johtamistyylin seurauksena syntynyttä epäjärjestystä enemmän kuin autoritaarisen johtamistavan seurauksena ryhmään syntynyttä vihamielistä ja ristiriitaista ilmapiiriä. 
Voidaanko demokraattista johtamistapaa pitää aina kiistatta parhaana? Tutkimukset tukevat voimakkaasti alkuperäistä oletusta demokraattisen johtamistavan ja työtyytyväisyyden välisestä yhteydestä. Demokraattisuudella on taipumus johtaa alaisten tyytyväisyyteen useammin kuin autoritaarisuudella, mutta johtamistavan ja tuottavuuden välillä ei ole löydetty pysyvää yhteyttä.

Tutkimusten mukaan demokraattinen johtajuus on tehokkainta, kun

- päätökset eivät ole rutiiniluonteisia

- informaatiota ei voi standardoida eikä keskittää

- päätöksiä ei tarvitse tehdä nopeasti ja kun alaiset

- haluavat toimia itsenäisesti

- arvostavat sitä, että saavat osallistua päätöksentekoon

- omaavat tietoja ja taitoja sekä näkemyksiä, joilla on merkitystä päätöksenteossa ja

- osaavat toimia itsenäisesti ilman valvontaa.

Michiganin yliopistossa Rensis Likertin johdolla vuonna 1947 aloitetun tutkimuksen tuloksena havaittiin, että korkean tuottavuuden osastoilla oli matalan tuottavuuden osastoihin verrattuna

- käytössä yleisluonteinen johtajuus pikemmin kuin tarkka johtamismenettely

- käytössä pikemmin demokraattinen kuin autoritaarinen johtamistyyli

- todennäköisemmin esimies, joka käyttää verraten paljon aikaa alaistensa johtamiseen ja melko vähän aikaa tehtävien hoitamiseen

- pikemmin henkilöstö- kuin tuotantosuuntautunut esimies

- todennäköisemmin esimies, joka piti saamaansa vastuuta ja valtaa tehtävien hoidon kannalta sopivana.

Matalan tuottavuuden osastojen esimiehet käyttivät autoritaarista ja tarkkaa johtamistapaa ja keskittyivät asioiden johtamiseen.

Likert rakensi johtamismallinsa työryhmätyöskentelyn ja osallistuvan johtamistavan varaan. Hänen mukaansa kiinteät ja lojaalit ryhmät ovat myös tuottavia. Kiinteitä ja lojaaleja työryhmiä ovat ryhmät, jotka luottavat itseensä ja joilla on korkea omanarvontunto. Likertin teoriassa johtajan rooli on aikaansaada yhteistyötä alaistensa keskuuteen ja toimia eräänlaisena välittäjänä alaistensa ja muiden organisaation osien välillä. Esimies on 'linkki", joka välittää organisaatiosta tulevia vaateita alaisilleen ja alaistensa aikaansaamia ratkaisuja organisaatiolle.

Vuonna 1945 käynnistettiin Ohion yliopistossa sarja johtamiseen liittyviä tutkimuksia. joukko eri tieteenalojen tutkijoita kehitti johtajan käyttäytymistä mittaavan kyselylomakkeen, jonka avulla analysoitiin johtamistyylejä eri tilanteissa ja erilaisissa ryhmässä.

Johtamiseen liittyvät arvioinnit ryhmittyivät kahdelle faktorille, joita alettiin kutsua tehtäväsuuntautuneisuudeksi ja ihmissuhdesuuntautuneisuudeksi. Tehtäväsuuntautuneisuus mittaa sitä, missä määrin esimies suunnittelee, ohjaa ja valvoo niitä toimintoja, joita hänen alaisensa tekevät. Ihmissuhdesuuntautuneisuus mittaa sitä, missä määrin esimies kykenee luomaan keskinäisen kunnioituksen, arvonannon ja luottamuksen ilmapiirin alaisiinsa ja missä määrin hän kykenee rakentamaan avoimen vuorovaikutuksen itsensä ja alaistensa välille.

Näillä kahdella ulottuvuudella on ollut suurempi merkitys johtamisen kentän hahmottamiseen, kuin millään muulla ulottuvuudella. Niitä on koulutettu mm. Robert Blaken ja Jane Moutonin johtamisruudukon sekä William Reddinin Kolmedee mallien avulla. 
Blaken ja Moutonin ajatuksena on, että tehtäväkeskeinen toiminta ja ihmissuhdesuuntautunut toiminta ovat toisiinsa nivoutuneita ja toisiaan täydentäviä toimintoja. Tuottavuutta ei saavuteta pelkästään tehtäväsuuntautuneella toiminnalla, vaan tuottavuuteen ja tehokkuuteen vaikuttaa se, missä m ihmiset kehittävät uusia toimintatapoja ja tuotteita sekä millä innolla ja niillä laadulla töitä tehdään.

Vastaavasti ihmissuhdesuuntautuneisuuteen kuuluu myös se, missä määrin ihmiset ovat sitoutuneet tehtäviinsä, kantavat vastuuta toiminnastaan, ovat yhteistyössä muiden työpaikalla olevien henkilöiden kanssa ja missä määrin he kokevat saavansa työstään arvostusta, kunnioitusta ja omanarvontuntoa.

\section{Tilannepainotteiset johtamismallit}

Sekä piirreteoriat että käyttäytymistä painottavat teoriat epäonnistuivat pyrkiessään selittämään johtamisen menestystekijöitä. Hakijat päätyivät siihen, että sekä piirreteoreettinen että käyttäytymistieteellinen lähestymistapa oli ollut liian yksinkertainen. Huomio käännettiin johtamisen ja ympäristöolosuhteiden välisiin, ehdollisiin (kontingentteihin) suhteisiin. Tilannepainotteisessa tarkastelussa nähtiin, että johtaminen on monimutkainen sosiaalinen prosessi, jossa johtajan vuorovaikutussuhteet muihin ihmisiin työskentelyn aikana ratkaisevat johtamisen onnistumisen.

Washingtonin yliopiston professori Fred Fiedler kiteytti 15 vuotta kestäneen johtamistaidollisen tutkimustyönsä johtamistyylien ja tilanteen ominaisuuksille perustuvaksi johtamisen kontingenssimalliksi.

Fiedler oli ensimmäisiä, jotka havaitsivat johtamisen ja sen ympäristön välisen vuorovaikutuksen tutkimisen tarpeen. Tutkimustensa tuloksena hän päätyi siihen, että johtamiseen vaikuttavat seuraavat ympäristötekijät:

- esimiehen ja hänen alaistensa väliset suhteet - tehtävärakenne ja

- esimiehen valta-asema hänen johtamassaan ryhmässä.

Empiiristen tutkimusten tulokset johtamistyylin ja tilanteen välisestä riippuvuudesta osoittivat, ettei ole olemassa yhtä, parasta johtamistyyliä, vaan johtamistyylin arvo riippuu siitä tilanteesta, jossa johdetaan. Tehtäväkeskeinen johtamistyyli sopii tilanteisiin, jotka ovat joko hyvin suosiollisia tai hyvin epäsuosiollisia johtamiselle. Ihmiskeskeinen johtamistyyli sopii tilanteisiin, jotka eivät ole suosiollisia mutteivät myöskään epäsuosiollisia johtamiselle.

Paul Herseyn ja Kenneth Blanchardin tilannejohtamismallissa oletetaan, että tietyn kypsyyden omaaville ihmisille soveltuu tietynlainen johtamistyyli. Niinpä ollakseen tehokas esimiehen olisikin muutettava johtamistapaansa alaisen kypsyystason mukaan. Mitä kypsempi alainen on, sitä vähemmän ohjausta hän kaipaa. Vastaavasti epäkypsä alainen kaipaa paljon ohjausta, kunnes hän ajan myötä kypsyy itsenäiseksi ihmiseksi.

\section{Yhdentävät johtamisteoriat}

Vaikka tilanneteoriat ovat jo pitkään olleet johtamisteorioiden valtavirtana, eivät ne ole kyenneet selittämään johtamisen onnistumista tai epäonnistumista juuri tehokkaammin kuin piirreteoriat tai käyttäytymisteoriat aikoinaan.

Piirreteorioiden, käyttäytymisteorioiden ja tilanneteorioiden tutkimustulokset ovat jonkin verran ristiriitaisia. Tämä aiheutuu ainakin osittain siitä, ettei mikään omaksutuista viitekehyksistä 
riittävästi ota huomioon muita näkökulmia. jos voitaisiin kehittää teoria tai malli, jossa otettaisiin huomioon piirreteoreettinen, käyttäytymistieteellinen sekä tilanneteoreettinen viitekehys, voitaisiin edetä kohti johtamiseen liittyvien tekijöiden todellista ymmärtämistä.

Eri näkökulmia yhdentävän mallin rakentaminen voitaisiin aloittaa miettimällä, mitkä ovat eri tekijöiden syy - seuraussuhteet toisiinsa nähden. Seuraavassa kuviossa on esitetty eräs lähtökohta muuttujien välisiksi riippuvuussuhteiksi.

\begin{tabular}{|l|c|r|}
\hline \multicolumn{3}{|c|}{ Tilannetekijät } \\
\hline $\begin{array}{l}\text { Johtajan } \\
\text { ominaisuudet }\end{array}$ & $\begin{array}{c}\text { Johtajan } \\
\text { käyttäytyminen }\end{array}$ & $\begin{array}{r}\text { Alaisten } \\
\text { reaktiot }\end{array}$ \\
\hline
\end{tabular}

Yhdentäviä johtamisteorioita ei ole toistaiseksi kyetty riittävästi empiirisesti kokeilemaan.

\section{Merkityksen johtaminen}

Edellä käsiteltyjä johtamisen teorioita leimaa ns. positivistinen tieteen traditio. Niissä on pyritty keräämään uutta tietoa johtamisesta havainnoimalla johtamisen syy-seuraussuhteita. Niissä sosiaalista todellisuutta on pidetty tosiasiapohjaisena ilmiönä, joka on objektiivisesti havaittavissa ja tutkittavissa. Lähtökohdat tällaiselle näkökulmalle on saatu luonnontieteistä, joissa ilmiöt ovat yllä kuvatun kaltaisia.

Tätä lähtökohtaa on kuitenkin viime aikoina yhä enemmän kritisoitu. On todettu, että sosiaaliset tosiasiat ovat ihmisten välisen vuorovaikutuksen, sopimisen ja tulkintojen tulosta. Ymmärtävän tai tulkitsevan näkökulman mukaan tutkijoiden olisi pyrittävä selvittämään, millaisia merkityssisältöjä ihmiset omaavat ja kuinka nämä merkityssisällöt ihmisyhteisöissä syntyvät. Tämän näkökulman mukaan johtamisella on suuri rooli merkityssisältöjen synnylle ja kiinteytymiselle. Merkityksen muovautumisessa on kiinnitetty huomiota mm. johtajan karismaattisuuteen ja "transformatiiviseen" johtajuuteen.

Johtamisessa on jo kauan puhuttu karismaattisesta johtajuudesta, joka perustuu johtajan erikoislaatuisille ominaisuuksille. Miten tällainen karsima syntyy? Voitaneen sanoa ihmisten antavan ihanteellistetun, karismaattisen, leiman henkilölle, joka kykenee muovaamaan heidän tajuntaansa näkökulman, jonka avulla esillä oleviin tilanteisiin ja ongelmiin kyetään vastaamaan tarkoituksenmukaisella tavalla.

Karisma liittyy merkityksen muotoutumiseen. Ihminen, joka kykenee luomaan uusia ajattelumalleja, joista tulee ihmisryhmän toiminnan perustana olevia ajattelumalleja, tulee ihmisryhmän ihannoimaksi johtajaksi.

Miten tämä tapahtuu? On tarkasteltava sitä, miten merkitys syntyy ja mitä pidämme totena. Yksilö pitää totena omia tavanomaiseen toimintaansa liittyviä ajatuksia, jotka eivät ole unelmia. Ryhmässä pidetään todellisina sellaisia ajatuksia, jotka vastaavat useimpien käsitystä. Voidakseen vaikuttaa viitekehykseen, jonka kautta useimpien käsitykset muotoutuvat, esimiehen on kyettävä muovaamaan todellisuutta.

Tämä voi tapahtua joko kriisitilanteiden tai uudenlaisten visioiden luomisen kautta. Kriisit avaavat tilanteita uudenlaisten ajatusmallien kokeiluun. Tavanomaisessakin tilanteessa esiintyy kuitenkin mahdollisuuksia monenlaisiin tulkintoihin. Esimies, joka kykenee luomaan uudenlaisia visioita, 
jotka vetoavat muiden (fenomenologisiin) kokemuksiin ja jotka luovat perustan yhteisille unelmille, kykenee muovaamaan alaistensa todellisuutta.

Tämän näkökulman mukaan johtaminen on prosessi, jossa yksi tai useampi henkilö onnistuu suuntaamaan tai jäsentämään muiden ihmisten todellisuutta.

Johtaja voi muovata alaisten todellisuutta $\mathrm{mm}$.:

1. Karisman kautta. Jos johtajalla on kykyä nähdä, mikä on tärkeää ja arvokasta, hän kykenee luomaan uskomuksen, että tavoiteltava päämäärä ja ryhmän omaama visio on arvokas ja merkityksellinen.

2. Yksilöllisen kohtelun kautta. Johtaja delegoi projekteja, joissa voi oppia uutta ja kiinnittää huomiota alaisten tarpeisiin. Johtaja kunnioittaa alaisiaan yksilöinä.

3. Älyllisten virikkeiden kautta. Johtaja esittää uudenlaisia näkökulmia ja kannustaa alaisiaan tarkastelemaan ongelmia uusista näkökulmista.

Karismaattinen johtaja kykenee jatkuvasti muovaamaan alaistensa maailmankuvaa uudenlaiseksi. Tästä maailmankuvasta tulee alaisille tiedollisella, toiminnallisella ja tunteen tasolla "todellisuutta". Alaisten fenomenologisen todellisuuden muotoutumisessa johtamisen seurauksena voidaan erottaa ainakin seuraavat tasot: 1) alaiset uskovat, että johtajan esittämät näkökulmat ovat tosia, 2) alaiset omaksuvat näkökulmat omikseen, 3) johtajasta pidetään, 4) johtajaan luotetaan sokeasti, 5) johtajaan samastutaan täysin, 6) alaiset sitoutuvat tunnetasolla ajamaan organisaation päämääriä ja organisaation syvintä tarkoitusta, 7) alaisten elämän päämääräksi tulee organisaation syvimmän tarkoituksen toteuttaminen ja heidän oma kasvunsa tapahtuu tämän pyrkimyksen kautta.

Merkityksen johtamisessa tarkastellaan sitä, miten se viitekehys, jota käytetään ilmiöiden ja tapahtumisen tulkinnassa sekä vaihtoehtojen valinnassa hyväksi syntyy. Näin merkityksen johtamisessa pyritään tarkastelemaan sitä, miten käyttämämme ajattelutavat syntyvät.

\section{KIRJALLISUUTTA AIHEESTA}

Artikkeliin liittyy kirjoittajan kokoama keskeisen johtamisaiheisen kirjallisuuden luettelo. Luettelo ei ole edellä olevan artikkelin yksilöityihin kohtiin viittaava lähteistö.

BASS, B. 1985. Leadership and Performance Beyond Expectations. London.

BASS, B. 1990. Bass \& Stogdill's Handbook of Leadership. Theory, Research and Managerial Applications. Third Edition. New York.

BENNIS, W. 1992. On Becoming a Leader. Kent.

BOYATZIS, R. 1982. The Competent Manager New York.

BRYMAN, A. 1992. Charisma and Leadership in Organizations. London.

CUMMINGS \& STAW 1990. Leadership, Participation, and Group Behavior Greenwich.

DRUCKER, P. 1971. Drucker on Management. London.

FIEDLER, E. 1967. A Theory of Leadership Effectiveness. New York.

HANNUKAINEN, T. 1991. Laatuyritykset. MET. Tampere.

HERSEY, P. \& Blanchard, K. 1975. Organisaatiokäyttäytymisen perusteet. Tapiola.

HICKMAN, G. 1990. Mind of a Manager Soul of a Leader: New York.

HOLMES, K. 1992. Total Quality Management. Chippenham.

HUMBLE, J. 1972. Management by Objectives. London.

HUNT \& BALIGA \& DACHLER \& SCHRIESHEIM (eds.) 1988. Emerging Leadership Vistas. Massachusetts. 
JUUTI, R .1989. Organisaatiokäyttäytyminen. Keuruu.

JUUTI, P. 1992. Yrityskulttuurin murros. Tampere.

JUUTI, R. 1995. Johtaminen ja organisaation alitajunta. Keuruu.

JUUTI, P. \& LINDSTRÖM, K. 1995. Postmoderni ajattelu ja organisaation syvällinen muutos. Helsinki.

JUUTI, P. \& VARJORANTA, T. 1993. Johtaminen, organisaatio ja yhteistoiminta metalliteollisuudessa. Työministeriö. Helsinki.

KOUZES, J. \& POSTER, B. 1987. The Leadership Chanllenge. San Francisco.

LIKERT, R. 1967. The Human Organization. Tokyo.

Likert, R. 1961. Nya metoder föt företagsledning. Stockholm.

MILLS, Q. 1991. Rebirth of the Corporation. New York.

NEAVE, H. 1990. The Deming Dimension. Knoxville.

ODIORNE, G. 1970. Management by Objectives. London.

REDDIN, W. 1975. Liikkeenjohdon tehokkuus.

RICE, A. K. 1965. Learning for Leadership. London.

STEEPLES, M. 1992. The Corporate Guide to Malcom Baldridge National Quality Award. Homewood.

TICHY, N \& DEVANNA, M. 1990. The Transformational Leader. New York.

WHITE, R. \& LIPPITT, R. 1960. Autocracy and Democracy. New York.

YULK, G. 1989. Leadersbip in Organizations. Englewood Cliffs. 